\title{
DIVERSITY OF LABELLAR MICROMORPHOLOGICAL STRUCTURES IN SELECTED SPECIES OF MALAXIDINAE (ORCHIDALES)
}

\author{
AgnieszKa KowalKowsKA ${ }^{1}$, HANnA B. MARgOŃSKA ${ }^{2}$ \\ ${ }^{1}$ Department of Plant Cytology and Embrylogy, University of Gdansk \\ Kładki 24, 80-822 Gdańsk, Poland \\ e-mail: dokakow@univ.gda.pl \\ 2 Department of Plant Taxonomy and Nature Conservation, University of Gdansk \\ Legionów 9, 80-441 Gdańsk, Poland
}

(Received: December 6, 2007. Accepted: November 27, 2008)

\begin{abstract}
There are no papers examining the labellar micromorphology in Malaxidinae in detail. The aim of this paper is to present the results of labellar micromorphology of our studies on Malaxidinae. The micromorphology of nine species was examined and described (calli, nectaries, OP structures, concavities). These species are divided into six groups of which the lip morphology probably represents different forms of attracting and rewarding pollinators. Group one consists of Disticholiparis gregaria and Platystyliparis aurita with characteristic globular nectary and pad-like callus. The second group with Liparis nervosa has two conelike convexities. The third one is represented by Liparis sutupensis with spread lip, the basal callus, and the epichile often eroding with age. The fourth group (Stichorkis cespitosum) has a massive hypochil with basal callus and delicate epichil. The fifth group (Microstylis ophioglossoides, Dienia ophrydis) is characterized by a lip with developed lateral lobes, three deep concavities in the middle part, an erect callus, and many raphide cells. Crepidium cf. rheedii and Crepidium dryadum from the sixth group have a three-lobed lip with entire or toothed mid-lobe, basal callus, cavity surrounded by a rim and $\mathrm{OP}$ structures with raphide cells.

We also emphasized the different way and place of nectar secretion in the subtribe and gave some suggestions about pollination strategies.
\end{abstract}

KEY WORDS: labellar micromorphology, pollination, Malaxidinae, Orchidaceae, light microscopy, scanning electron microscopy.

\section{INTRODUCTION}

Plants create a lot of structures and mechanisms to attract and reward pollinators. In descriptions of different pollination strategies it is reported that the flowers' teasers as colour and scent play at first a major role and then rewards are in the second place (Proctor et al. 1996). In Orchidales rewards as nectar, pollen, pseudopollen, oil and wax enhance pollinators to visit the flower. More complex strategies like pseudocopulation and pseudoantagonism are well-known in Orchidales (van der Pijl and Dodson 1969). Some species produce carrion smell which attracts dipteran flies or stingless bees (Roubik 2000).

The major orchid attractant is nectar (van der Pijl and Dodson 1969; Arditti 1992; Dressler 1993). There are many different types of nectaries. The term "nectary" itself suggests where it is produced and offered being visible for pollinators, but does not imply the same origins and positions for all types of nectaries (Pacini et al. 2003). Nectaries may occur on plant surfaces or inside the plant body as well. The liquids may be produced in tubular nectar tubes in the ovary, e.g. in Cattleya, Brassavola or in labellar superficial grooves, e.g. in Listera, Bulbophyllum, Epipactis. More specialized orchids form a spur developing from tepals (van der Pijl and Dodson 1969). The secretory cells of the nectary by which the nectar is exuded may be ordinary epidermal cells, trichomes or nectariferous parenchyma cells where nectar is transported into specialized intercellular spaces and outside through stomata (Fahn 1979, 1988a, b).

Specific features of the flower: visual and olfactory stimuli combined with perceptive abilities of pollinators and tactile stimuli and rewards are related with specialization for particular pollinators, and even specific sex of them, e.g. Huntleya meleagris is pollinated by male Euglossinae bees (van der Pijl and Dodson 1969).

From taxonomic, morphological and also ecologic point of view Malaxidinae belong to a very interesting group of Orchidales. The basic taxonomic problems within Malaxidinae were e.g. lack of clear and univocal criteria distinguishing taxa on both genera and species levels, ignoring by 
researches the original diagnoses and type-specimens as only valid reference materials, as well as time dispersion, difficulties in localisation, and sometimes destroying of type-collections; some taxa are known only from single typespecimens etc. In effect of many taxonomic and nomenclatural problems numerous taxa were polymorphic and artificial, with species gathered on the basis of superficial similarity and cursory determinations. During the recent research many taxonomic problems within the subtribe were solved (Margońska and Szlachetko 2001a-c, 2004, 2006; Margońska 2002, 2003, 2005a-c, 2006a, b, 2007; Szlachetko et al. 2008; Margońska and Kowalkowska 2008).

Nowadays Malaxidinae include 22 genera and over 800 species. The orchids are characterized by small, relatively equal vegetative structures, with numerous, comparatively minute, differential and often variable flowers, gathered at apical inflorescences. Indication of the most significant taxonomic features for the whole subtribe is easy. With no doubt the morphology of flowers, particular lip and generative structures are the most essential for the most of genera, but e.g. for Seidenforchis or Liparis sensu lato (Liparis sensu stricto, Stichorkis, Disticholiparis etc.) group the forms of plants are also important. At present, after taxonomic revision of the most genera, combination of morphological features seems to be significant on species level: developing of distal (lack, present and form of teeth), basal (lack, present and form of auricles) parts of lip, its convexities and concavities.

However the subtribe is cosmopolitan, most of the species are occurring in the tropical and subtropical areas. Malaxidinae are terrestrial and epiphytic, rarely lithophytic species. The relatively high degree of diversity of the orchids is caused by different habitations and wide distribution. It results in a rather large number of endemic taxa and in consequence an increase of dangers - destruction of a few stands can bring about a disappearance of a taxon.

The knowledge of ecology and biology of many species is very poor. Especially, information about the orchids pollinators are very parsimonious, mostly based on often accidental observations or few notes of specimen's collectors.

According to the above, the researches by means of scanning electron microscopy may give solutions for the mentioned problems. SEM has been used for the general study of epidermal surfaces (e.g.: Barthlott 1981; Christensen and Hansen 1998; Davies and Winters 1998; Davies et al. 2003; Stpiczyńska and Matusiewicz 2001; Stpiczyńska et al. 2003; Stpiczyńska et al. 2005; Bonatti et al. 2006). Nevertheless, there are not many publications on floral micromorphology, which perhaps is related to difficulties with

TABLE 1. Species of Malaxidinae used in the studies and numbers of groups, which they are placed in.

\begin{tabular}{ll}
\hline Species & Group \\
\hline Crepidium rheedii Bl. & 6 \\
Crepidium dryadum (Schltr.) Szlach. & 6 \\
Dienia ophrydis (Koen.) Ormerod \& Seidenf. & 5 \\
Disticholiparis gregaria (Lindl.) Marg. \& Szlach. & 1 \\
Platystyliparis aurita (Ridl.) Marg. & 1 \\
Stichorkis cespitosum (Lam) Thouars ex Marg. & 4 \\
Liparis nervosa (Thunb.) Lindl. & 2 \\
Liparis sutepensis Rolfe ex Downie & 3 \\
Microstylis unifolia (Michx.) Britton & 5 \\
\hline
\end{tabular}

flowers availability, fragility and special procedure of sample preparation (Clark et al. 1986; Davies and Winters 1999). In Malaxidinae only Capeder (1898) described developmental stages of gynostemium in Malaxis monophyllos (Microstylis monophyllos (L.) Lindl.) and Kurzweil (1987) in Malaxis commelinifolia (Crepidium commelinifolium (Zoll. \& Morren) Szlach.). There are no works on lip micromorphology in these species.

\section{MATERIALS AND METHODS}

The materials were young and adult flowers of chosen species of Malaxidinae (Table 1). The samples were collected at natural stands or gathered at different cultures (voucher list available from the authors). Malaxidinae flowers are small, very delicate and fragile. The used flowers were fresh, dry or conserved in liquid: Kew (ethanol-formaldehyd-glycerine water solution) or Copenhagen Mixture (ethanol-glycerine water solution). Using of cool light of optical fibre illumination for stereomicroscope prevented fresh and wet samples from drying and destruction. The dry samples for protection of their structure before researching were soaked only in warm distilled water.

For observations in scanning electron microscope (SEM) flower lips were preserved in Kew or Copenhagen Mixture. The plant material was dehydrated through ethanol series. After following critical-point drying in a Critical Point Dryer Emitech K850 apparatus, the specimens were mounted onto the surface of SEM stubs that had been covered with a SPI Carbon Conductive Double Sided Adhesive Disc. The stubs were gold-coated (Sputter Coater Spi-Module $220 \mathrm{~V}$ for $120 \mathrm{~s}$; sometimes the additional period of mounting time was experimentally examined and sometimes additional 20-30 s were necessary. The samples were examined and imaged in a Phillips XL-30 Scanning Electron Microscope operating at an accelerating voltage of $15 \mathrm{kV}$, and spot mag 5 .

In SEM study we used the surface characters written by Barthlott (1981) and Davies and Winters (1998). Nevertheless Barthlott described mainly the seed surface, giving division of epidermal surface characters grouped in four categories which can be useful also in describing labellar cells. The labellar epidermis indicating the potentially useful labellar characters in Maxillaria species is well-described by Davies and Winters. Instead of using terms describing labellar morphological appearance: homogeneity / heterogeneity, it would be preferred to use terms: uniform / non-uniform which are synonyms, but do not indicate the phylogenesis. This term also was used by Kurzweil (1987) describing morphological unity of features in gynostemia.

For interpretation the lip in Malaxidinae species characters combined from Barthlott (1981)* and Davies and Winters (1998) ** were used:

1) Cellular arrangement*; Lip: uniform or non-uniform (surface glabrous or not; with/without papillae)**.

2) Shape of cells - the "primary sculpture" of the surface (outline of cells; anticlinal walls; relief of cell boundary; curvature of outer periclinal wall)*.

3) Relief of outer cell walls (the "secondary sculpture") caused by cuticular striations*.

4) Epicuticular secretions (the "tertiary structure")*. 


\section{RESULTS}

\section{Light microscopy}

While working out the taxonomic revision of Malaxidinae we have studied morphology and anatomy in these groups of species. The studies on fresh, dried and preserved in liquid, among others, flower samples, conducted mainly by using stereomicroscopy and classic microscopy, let us select species representing the six preliminary groups of which the lip morphology probably representing different forms of attracting and rewarding pollinators.

The first set includes species of Platystyliparis and typesection of Disticholiparis. These orchids are epiphytes from the tropical forest. The studies were conducted on samples of Disticholiparis gregaria and Platystyliparis aurita. Lip of the orchids is characteristically geniculately recurved down just below its basal callus. The callus is padlike at the basal part, usually covering from above nectary and hold off the column of gynostemium. The nectary is globular, opening just above lip blade and directed to the front of the flower. The hypochil is thick and rather massive, while epichile is thinner with different micro-ornamentations. Both species, just below the nectary, have a smooth concavity ("throat of nectary").

The second group consists in the majority of tropical species Liparis sensu stricto. As representatives of the group we chose Liparis nervosa (Fig. 1) - the well known and widely distributed, terrestrial species. Lip of the orchid is recurved down about half of its length. The callus lip is adjoining the base of gynostemium column. It is ornamented by two frontally directed, conelike convexities and an obscure concavity between them, situated just above the lip blade. The concavity is probably a place of secreting a small quantity of nectary. From the concavity, nearly along the whole lip length there is a narrow and obscure depression. The hypochil is thick, with thick and rigid strip at lateral margins, whereas the alternative epichile is thin-

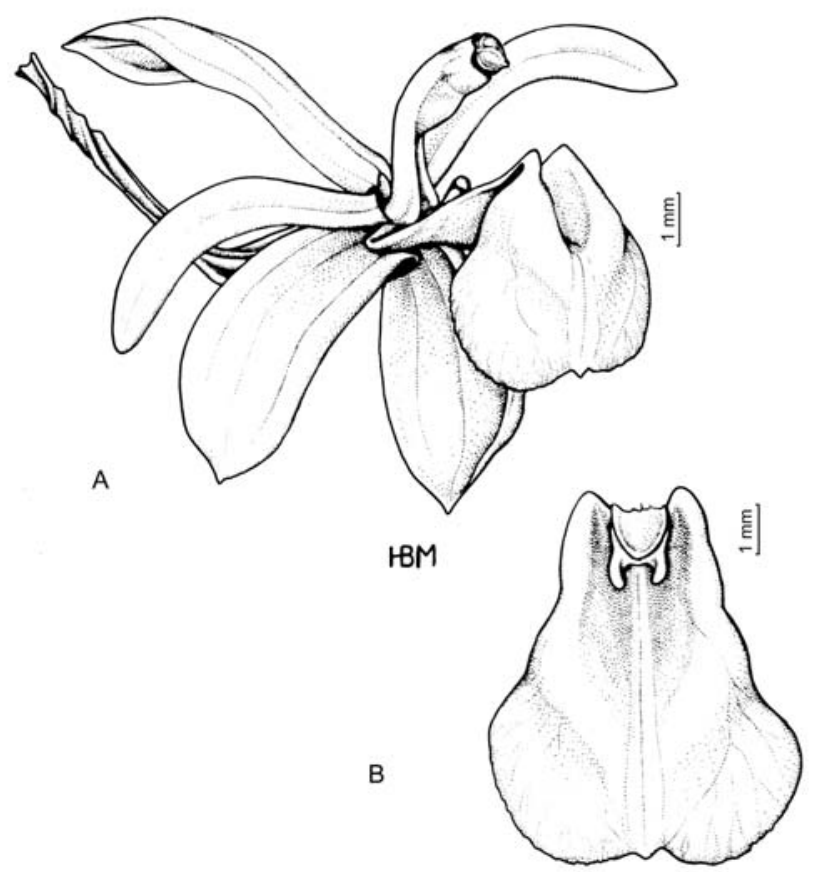

Fig. 1. Liparis nervosa (Thunb.) Lindl.: A - flower; B - lip (India, Hooker f. and T. Thomson s.n. (K!) (Margońska).

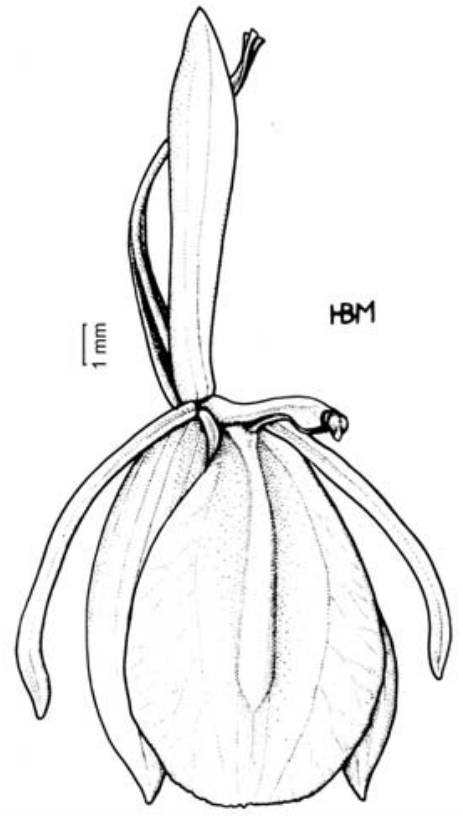

Fig. 2. Liparis sutupensis Rolfe ex Downie: A - flower (India, Hooker f. and T. Thomson s.n. (K!) (Margońska).
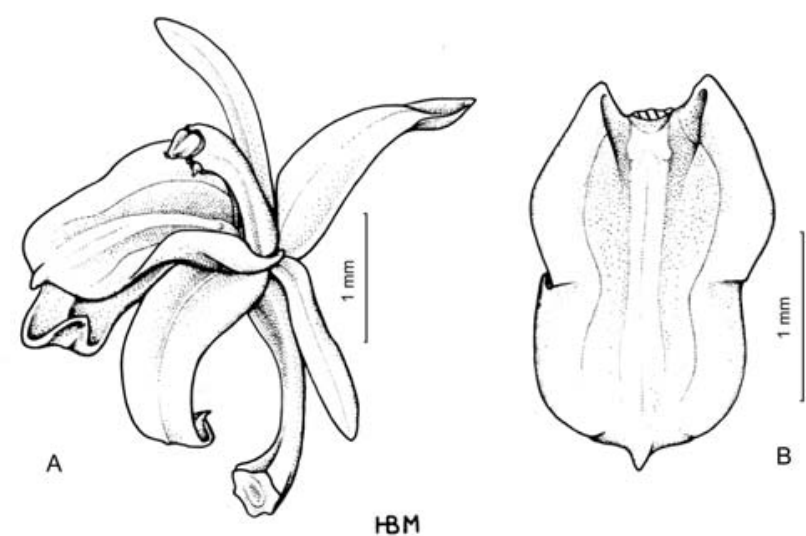

Fig. 3. Stichorkis cespitosum (Lam) Thouars ex Marg.: A - flower; B lip (Reunion, Leg. Jussieu s.n. (HOLO-P!) (Margońska).

ner, widely spread, with age often eroding at distal margins.

The third group includes also terrestrial species of Liparis sensu stricto, but mostly from colder and more open localizations (e.g. Liparis sutepensis (Fig. 2)). These plants have erect, flatways spread lip, without any recurvation. The basal callus is similar to these from the second group but the secreting concavity is quickly becoming flattened, fleshy and convexed strip. The epichile is only slightly thinner than hypochil and often distally eroding with age.

The fourth group is represented by tropical epiphyte Stichorkis cespitosum (Fig. 3). Its lip has features similar to orchids from the first and the second groups - is recurved down about half of its length, with convexed "throat of nectary". The thick and massive hypochil is a landing place on which insects may easily sit. The epichile is more delicate and more attractive for the pollinator's complex eyes. The callus is analogous with the second and the third groups.

Microstylis unifolia and Dienia ophrydis (Fig. 4) from the fifth group are characterized by lip with well developed lateral lobes, large and deep three concavities covering the whole middle part of the lip blade, basally closed by erect 

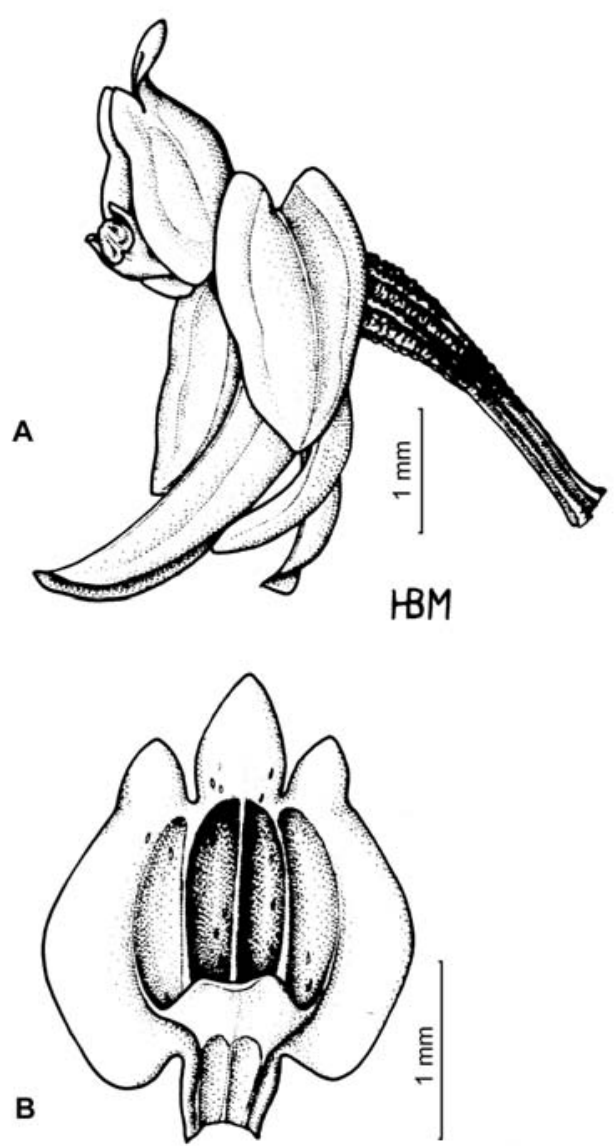

Fig. 4. Dienia ophrydis (Koen.) Ormerod and Seidenf.: A - flower; B lip (India Orientalis, Koeonig s.n. (LECTO-K!) (Margońska).
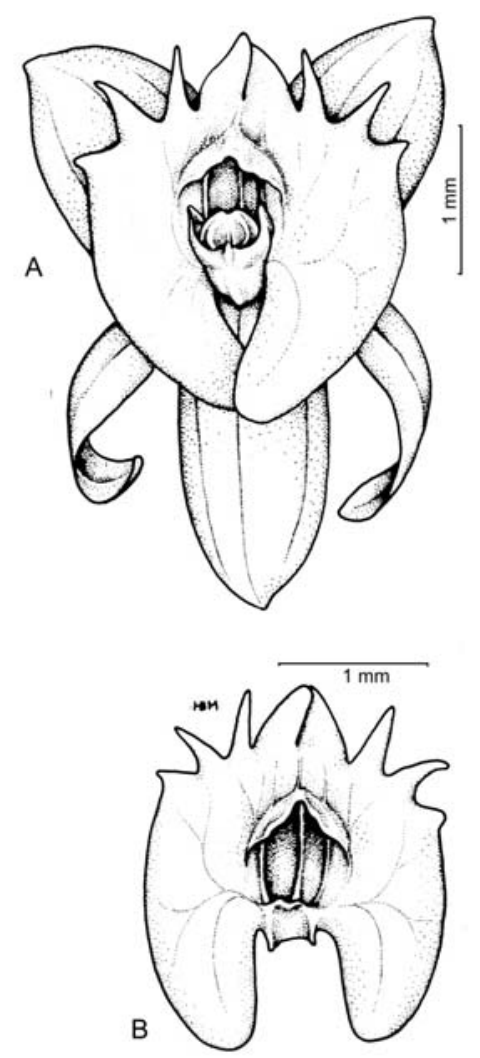

Fig. 5. Crepidium rheedii B1.: A - flower; B - lip (Indonesia, Blume s.n. (HOLO-P!) (Margońska). callus (adjoining the base of gynostemium column); many large raphide cells are spread on the whole surface and also aggregated around some lip areas.

The sixth group covers species of Crepidium (Fig. 5). They are epiphytic and terrestrial plants from tropics and subtropics, with specific shape of lip. Lips are always 3-lobed; mid-lobe can be entire or more or less splitted apically; lateral lobes are well developed, with distal margins entire or toothed, mostly with large, prominent over the gynostemium base and directed down auricles. The central cavity is surrounded at least by slightly convex rim, with thickening often forming a roof apically. Basal callus, presence and arrangement of raphide cells are similar like in the fifth group.

All representatives of Malaxidinae have cells with raphide crystals, which in simple light are visible, yet in UV are distinctly shinning. In case of their localizations (around nectar concavities and gynostemium's elements) probably they are a part of nectar guides. Malaxidinae usually produce a light scent, resembling the smell of e.g. fish or cucumber (only sometimes sweet), which suggests pollination by Diptera, but field works are necessary.

\section{SEM}

After studies using light microscopy six groups were selected. SEM studies revealed further variability of characters in these groups. Cellular pattern is in these species non-uniform, but without trichomes. The "primary sculpture" is similar: isodiametric outline of cells, straight anticlinal walls and channeled relief of cell boundary, flat or convex periclinal walls. The main differences are in "secondary" and "tertiary sculpture" and these features will be the focus in describing species. These features are expressed by Barthlott (1981) as taxonomic important.

The concavity ("throat of nectary") occurs in Platystyliparis aurita and Disticholiparis gregaria (first group) (Fig. $6)$. Nevertheless the lip surface in both species is non-uniform, epidermis around the nectary is a little bit different rather smooth in Disticholiparis and with irregular striations in Platystyliparis. Much more visible striations are on the cells covering the two protuberances occurring only on the lip of Platystyliparis. In both species the small canal leads from nectary to $1 / 3$ length of the lip. Then, the cells are slightly flattened, but do not form the canal. Their surface is different from cells on margins, and it is visible as a tract from nectary to the apex of the lip. This tract is better recognizable in Disticholiparis by more smooth cells. In both species, irregular cuticular striations on the marginal and apical cells were observed. In Disticholiparis conical papillae on the folds also occur.

SEM observations revealed that in the non-uniform lip of L. nervosa (the second group, Fig. 7) the apical one third is covered by papillate cells. The cells on the callus and concavity are smooth. Only one stoma was found between the parallel arranged papillae.

The flat-spread lip of Stichorkis sutupensis (third group, Fig. 7) has smooth epidermis on callus, but on the margins the epidermis is irregularly striated and with ageing the borders become erose. The central tract from the callus towards the apex is alike in Disticholiparis gregaria and Platystyliparis aurita.

The characteristic feature of the next group (four) - Stichorkis cespitosum (Szlachetko et al. 2008) (Fig. 8) is the 

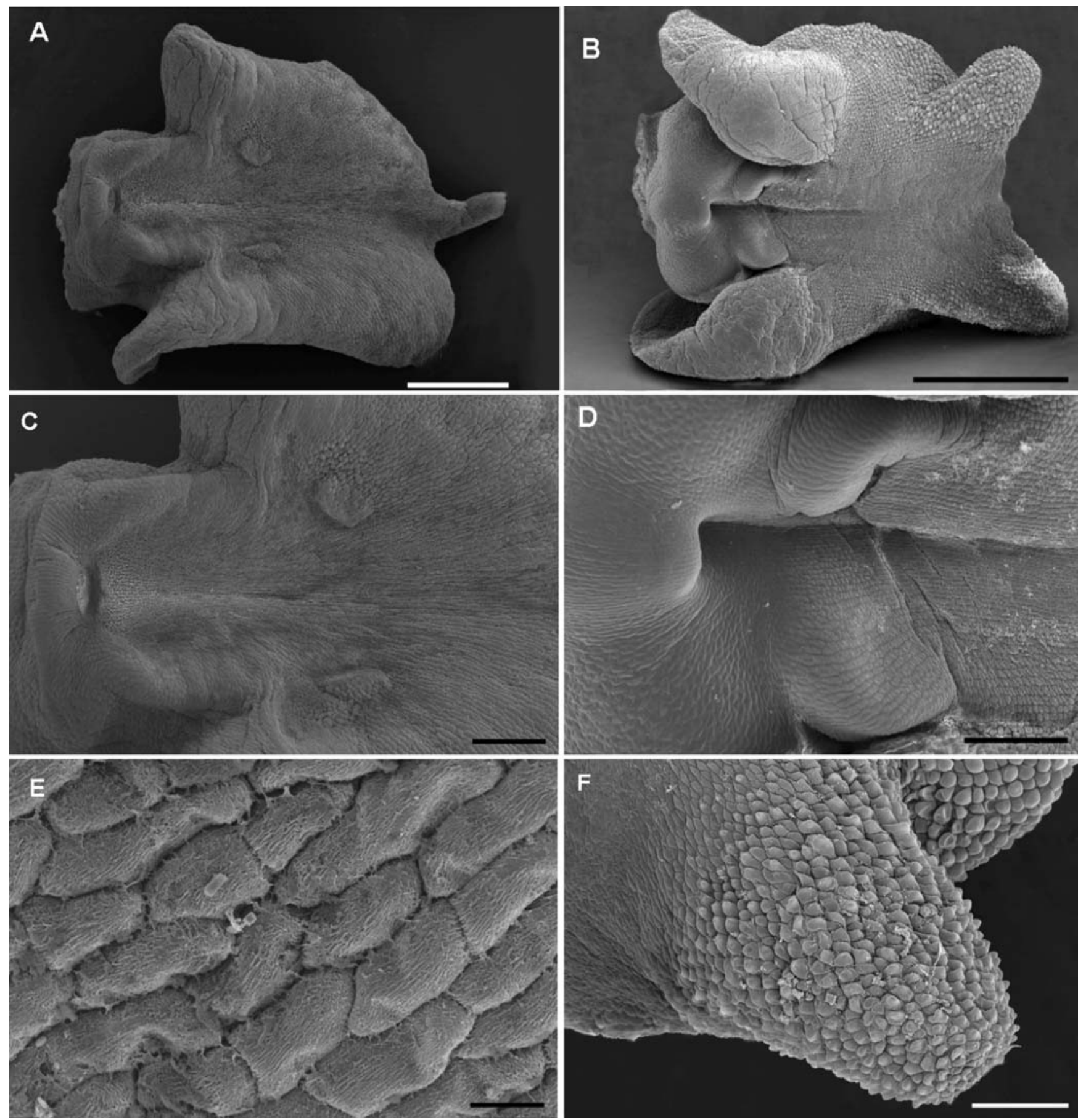

Fig. 6. Group 1: Platystyliparis aurita: A - lip, C - "throat of nectary", E - irregular striations on the cells at the apical part of the lip; Disticholiparis gregaria: B - lip, D - "throat of nectary", F - fissures on cells at the apical part of the lip. Scale bars: A - $500 \mu \mathrm{m}$; B - $1 \mathrm{~mm}$; C, D, F - $200 \mu \mathrm{m}$; E - $20 \mu \mathrm{m}$ (Kowalkowska).

small callus at the base of lip (feature sometimes omitted in light microscopy studies). Similar to the first group there is also a visible central slightly concave canal. The epidermis of the cells was difficult to describe because of easily dehiscent very fragile flower. It is supposed that the epidermis is irregularly striate similar to Stichorkis sutupensis.

The cellular arrangement in the fifth group (Microstylis unifolia and Dienia ophrydis; Fig. 9) is also non-uniform with tabular flattish epidermis and some bigger cells with the oxalate package structures (OP). In Microstylis unifolia the crystalline material from the concentrated in the midlobe OP structures was tipped to the cavity during sample preparation. In both the species there are still a lot of remains of secreted substances in the middle of the lip (even after treating the flower by several reagents). The lateral lobes are also covered by viscid substances. During the sample preparation the lip of Microstylis unnaturally pucked up, so some parts of margins are destroyed.

Characteristic for the sixth group (Crepidium cf. rheedii, Crepidium dryadum; Fig. 10) is the thickening around the cavity called lamina containing the bulbous cells with raphides (OP structures). These cells are placed on the bottom of the cavity, too. In Crepidium cf. rheedii the epidermis on lateral lobes and on teeth is smooth. In case of Crepidium dryadum there was no possibility to determine if cells have striations or not, because of the destruction of very fragile lip, however it is still sure that also in this species the OP structures occur in a great quantity. 

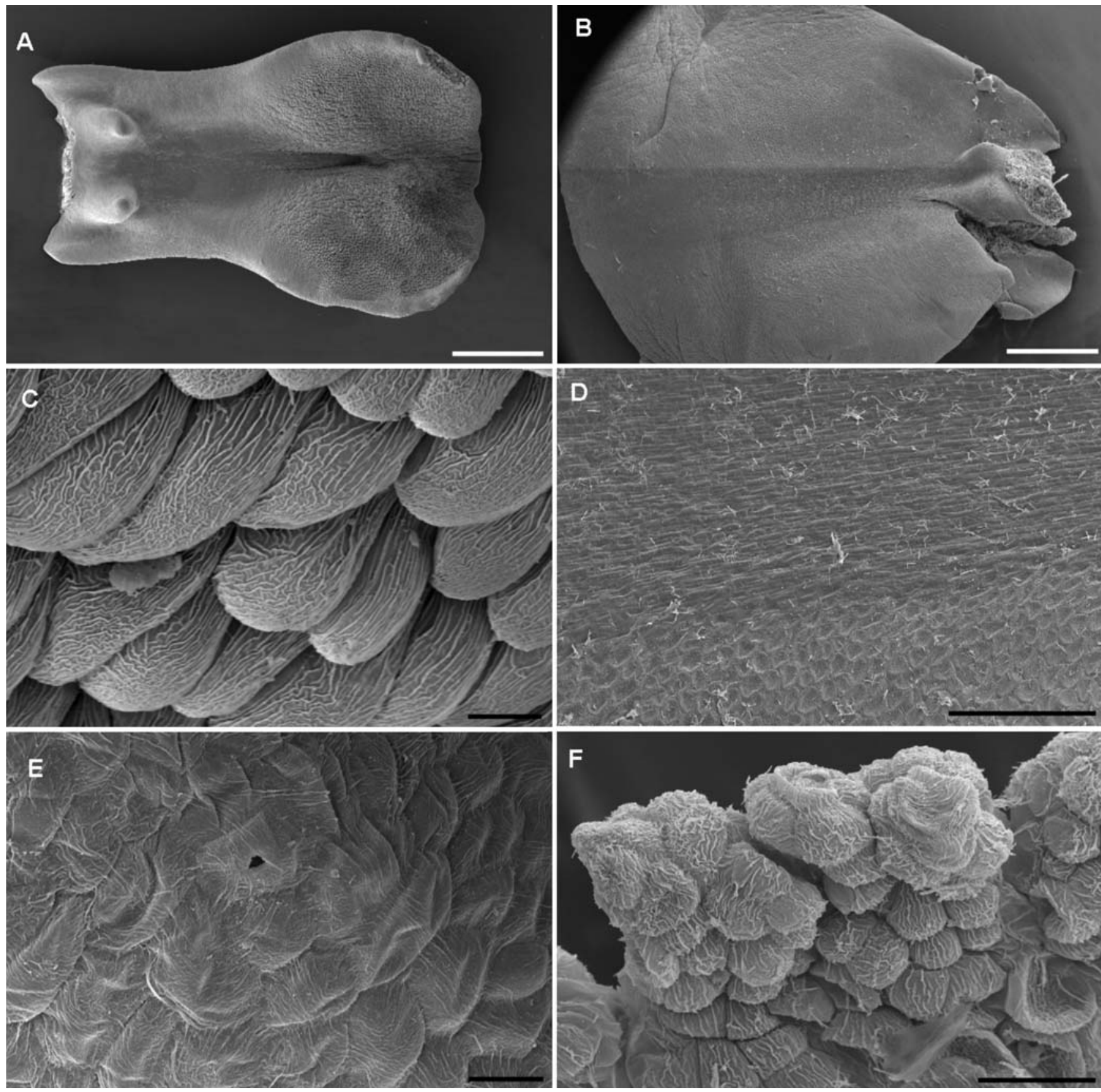

Fig. 7. Liparis nervosa: A - lip, C - striations on papillae at apical part of lip, E - single stomata; Stichorkis sutupensis: B - lip; D - the middle of the lip, F-erose cells on the margins of lip. Scale bars: A, B - $1 \mathrm{~mm}$; C, E - $20 \mu \mathrm{m} ; \mathrm{D}-200 \mu \mathrm{m} ; \mathrm{F}-50$ um (Kowalkowska).

\section{DISCUSSION}

The nectar on the lips of Disticholiparis gregaria and Platystyliparis aurita (group 1; Fig. 6) is probably leaking towards the epichil of the lip. The "throat of nectary" is distinct and well visible for pollinators. At the half of the lip's length of Platystyliparis aurita there are two protuberances. The importance of these structures is still unknown, which is specific for this species. In this group we observed cells' striations on the margins and at the apical part of the lip, which were also noticeable in stereoscope microscope. They possibly play the role for bordering the leak of nectar allowing its dripping through the center of the lip. Both species produce a scent resembling a fish or a cucumber. The smell suggests that they are pollinated by Diptera, but there is no evidence from field work.
The second group of flowers represented by Liparis nervosa (Fig. 7) has a lip with basal calli. The papillate cells at the apical part of the lip may function as an osmophore. Between them we found the only stomata. Without complex studies of this aggregation of species there is no possibility of any credible claims, however.

Liparis sutepensis (Fig. 7) in the third group has structures similar to the previous group, but because of the flatspread lips they are probably visited by different groups of insects. Having the basal calli, the lip of Stichorkis cespitosum (group 4; Fig. 8) is similar to Liparis nervosa and $L$. sutupensis. The striations on the margins and central tract for leaking nectar are alike in Disticholiparis gregaria and Platystyliparis aurita.

In the next group (5; Fig. 9) in species Dienia ophrydis basal calli or the basal cells probably produce nectar that 

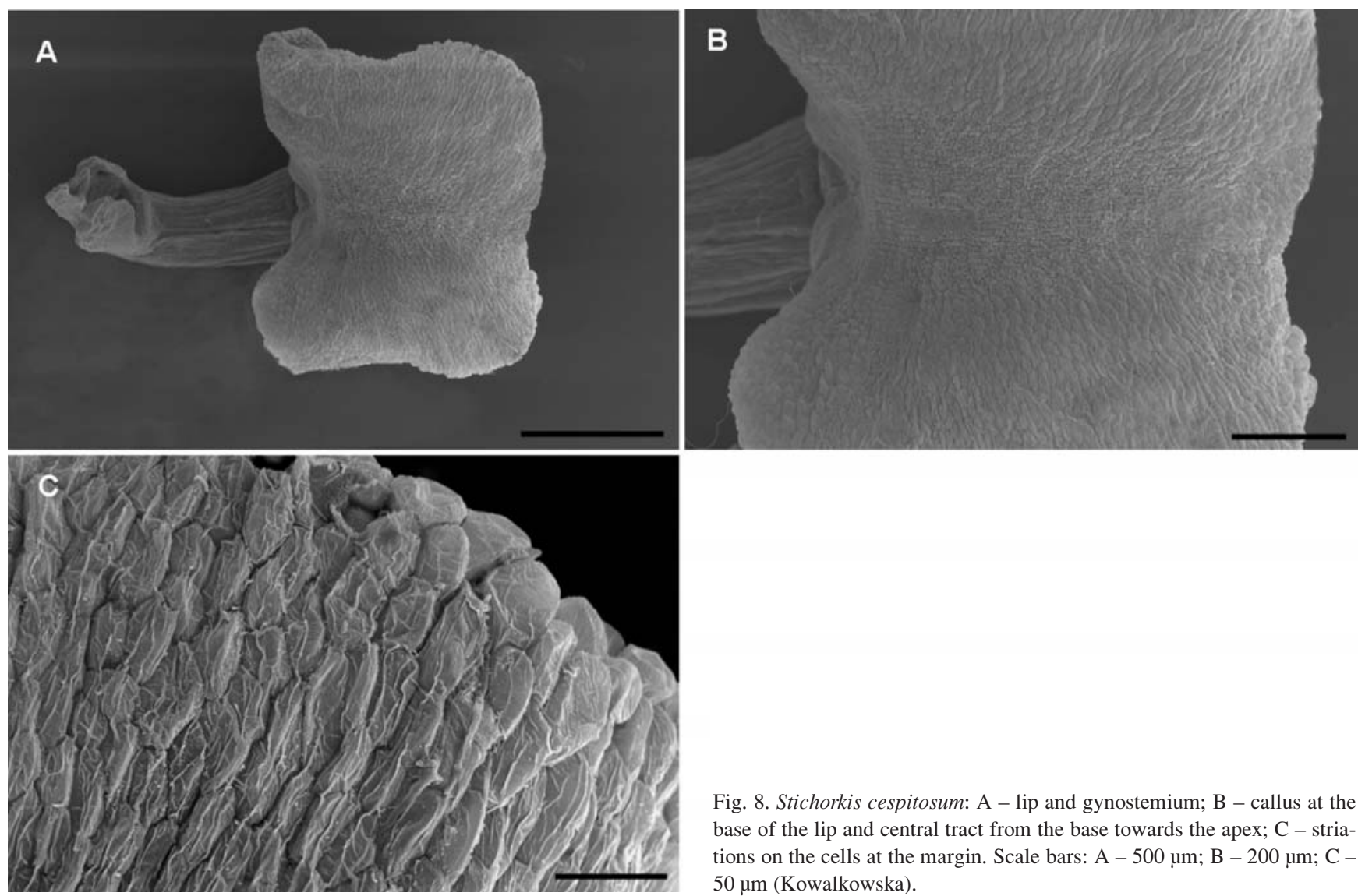

Fig. 8. Stichorkis cespitosum: A - lip and gynostemium; B - callus at the base of the lip and central tract from the base towards the apex; $\mathrm{C}$ - striations on the cells at the margin. Scale bars: A $-500 \mu \mathrm{m}$; B - $200 \mu \mathrm{m}$; C 50 um (Kowalkowska).

fills the cavity. In Microstylis unifolia raphides from midlobe cells were tipped to the cavity during sample preparation. The lateral lobes are covered by viscid substances. Also flowers of Crepidium rheedii and Crepidium dryadum (group 6; Fig. 10) attract pollinators by the glistening rounded cells which contain the OP structures with raphides. The toothed or waved lamina also plays a significant role in attracting insects.

In Malaxidinae only Hashimoto (1993) described raphide bundles on the lip in Malaxis khasiana (Crepidium khasianum (Hook.f.) Szlach.), M. acuminata (Crepidium acuminatum (D.Don) Szlach.), M. bancanoides (Crepidium bancanoides (Ames) Szlach.) and few on and in the inner tissue in M. latifolia (Dienia ophrydis (Koen.) Ormerod \& Seidenf.). He noticed that in these alliances the raphides ("needle-like crystals enclosed by the frail cell membrane") are placed in the areas near the gynostemium. He suggested that they function as a protecting pollination against herbivores, or to trace "a vectorial course" to the raphidefree gynostemium area for insects.

The raphides are forms of structures called by D'Arcy et al. (1993) the oxalate packages (OP). If the OP is an apomorphy, which is no longer an adaptive structure and has different function in taxa, so perhaps in Malaxidinae the glistening bundle of raphides may enhance pollinators to visit the flower. The flowers in this group are very small and often pale, so they may increase their reproductive success by producing well-visible for insects intriguing bulbous cells. Moreover, after release from cells, the oxalate crystals glisten on the surface of the lip. In the genus Stelis Sw. (Chase and Peacor 1987; Christensen 1992; van der Cingel 2001) they imitate the proper nectar which is called pseudonectar. Are the crystals occurring in the ways of in- sects deter herbivores or/and give the direction to gynostemium also in Malaxidinae? or maybe in some Malaxidinae species, like in Stelis, it is pseudonectar? - further studies are neccessary.

According to our studies, we suggest possible pollinators' position on flowers which results in attractants' occurrence. In the first group insect may land on the massive gynostemium having its head downwards and while reaching the nectar the pollinia may be placed on its ventral side of the body. In the next three groups (two, three and four) the insect cramming in the flower and reaching nectar may probably leave the carrying pollinia on the viscid stigma, which is the most common way of pollination. When it is going back, it hooks the viscidia and pulls out the locules with pollinia on its back side. Within groups five and six the insect may sit on the gynostemium trying to reach the nectary hiding behind the back and the pollinia are placed on its ventral side of the body.

In Malaxidinae many aspects connected with secretion of nectary, the characteristics of attractants for pollinators need explanation. Besides using traditional methods, TEM (transmission electron microscopy), cytochemistry may reveal responses for these questions.

\section{ACKNOWLEDGEMENTS}

We are grateful to Prof. dr hab. Jerzy Bohdanowicz, Department of Plant Cytology and Embryology, Gdansk University, Poland for scanning electron microscopy facilities available for this research. This article was prepared thanks to the Polish Ministry of Science and Higher Education grant No. N304 029 32/1584. The studies were conducted 

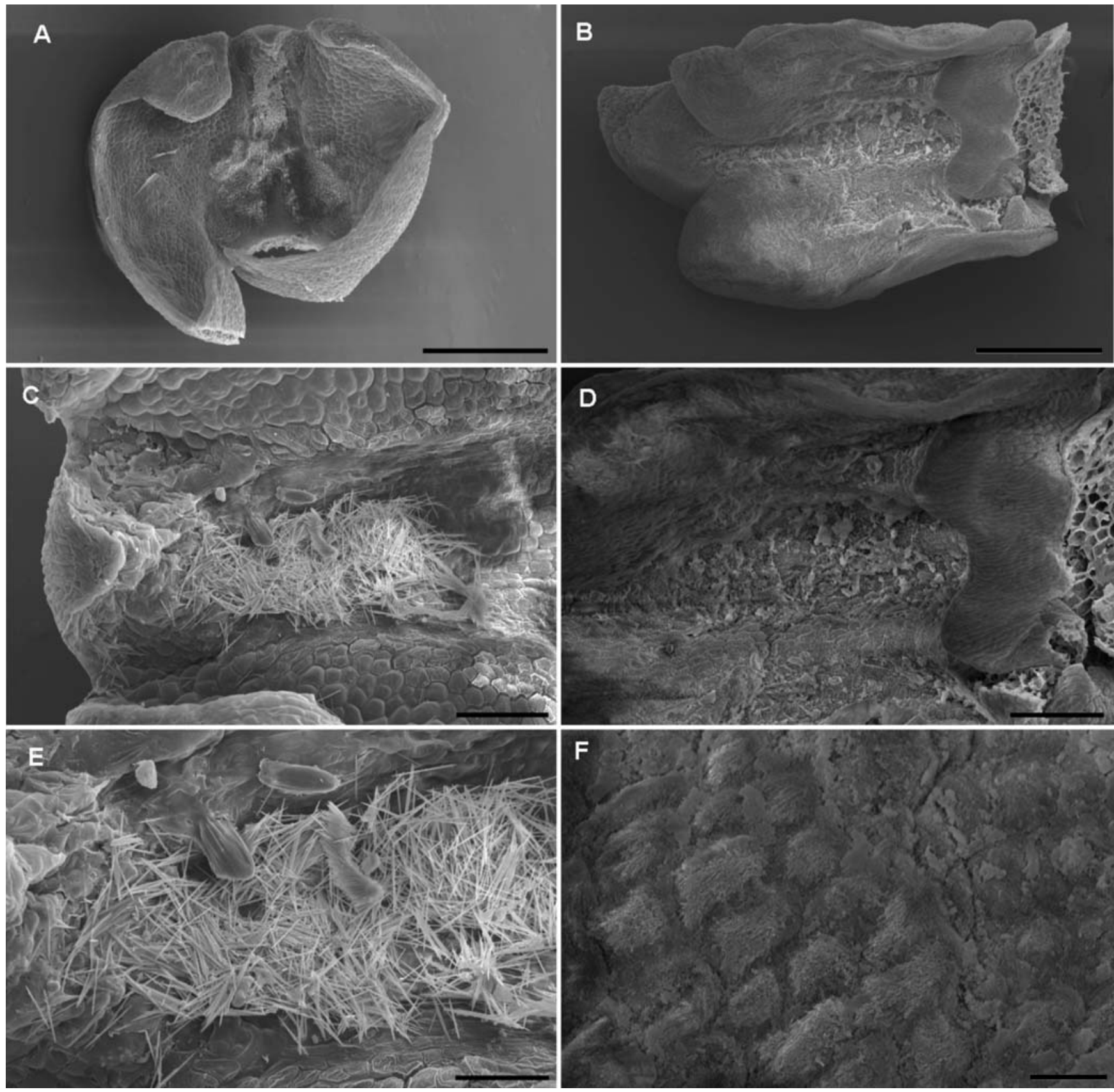

Fig. 9. Microstylis ophioglossoides: A - lip; C - the middle of the lip filled with raphides; E - crystals; Dienia ophrydis: B - lip ; D - cavity (see: huge amount of remains of secreted substances); F - cells with striations covered by viscid substances. Scale bars: A, B - $500 \mu \mathrm{m} ; \mathrm{C}-100 \mu \mathrm{m}$; D - $200 \mu \mathrm{m}$; E $50 \mu \mathrm{m} ; \mathrm{F}-20 \mu \mathrm{m}$ (Kowalkowska).

also with usage of the digital database - Archivum Orchidalium $^{2}$ and Database of Orchid Ultrastructure (DOUL) ${ }^{1}$.

\section{LITERATURE CITED}

ARDITTI J. 1992. Fundamentals of orchid biology. New York: John Wiley \& Sons, 704 pp.

BARTHLOTT W. 1981. Epidermal and seed surface characters of plants: systematic applicability and some evolutionary aspects. Nord. J. Bot. 1: 345-355.

BONATTI P.M., SGARBI E., PRETE C.D. 2006. Gynostemium micromorphology and pollination in Epipactis microphylla (Orchidaceae). J. Plant Res. 119: 431-437.

CAPEDER E. 1898. Beitrage zur Entwicklungsgeschichte einiger Orchideen. Flora 85: 368-423.

CHASE M.W., PEACOR D.R. 1987. Crystals of calcium oxalate hydrate on the perianth of Stelis Sw. Lindleyana, 2: 91-94.
CHRISTENSEN D.E. 1992. Notes on the reproduction biology of Stelis argentata Lindl. (Orchidaceae: Pleurothallidinae) in eastern Ecuador. Lindleyana 7: 28-33.

CHRISTENSEN K.I., HANSEN H.V. 1998. SEM-studies of epidermal patterns of petals in the angiosperms. Opera Bot. 135: 1-91.

CINGEL van der N.A. 2001. An Atlas of Orchid Pollination: America, Africa, Asia and Australia. Rotterdam, A.A. Balkema, 296 pp.

CLARK C., SANDERS D.L., CHAREST N. 1986. A field-orientated technique for producing high-quality preparations of plant surfaces for scanning eletron microsopy. Taxon 35(2): 295-297.

DAVIES K.L., WINTERS C. 1998. Ultrastructure of the labellar epidermis in selected Maxillaria species (Orchidaceae). Bot. J. Linn. Soc. 126: 349-361.

DAVIES K.L., WINTERS C. 1999. Scanning electron microscopy in orchids. Orchid Rev. 107(1229): 286-288. 

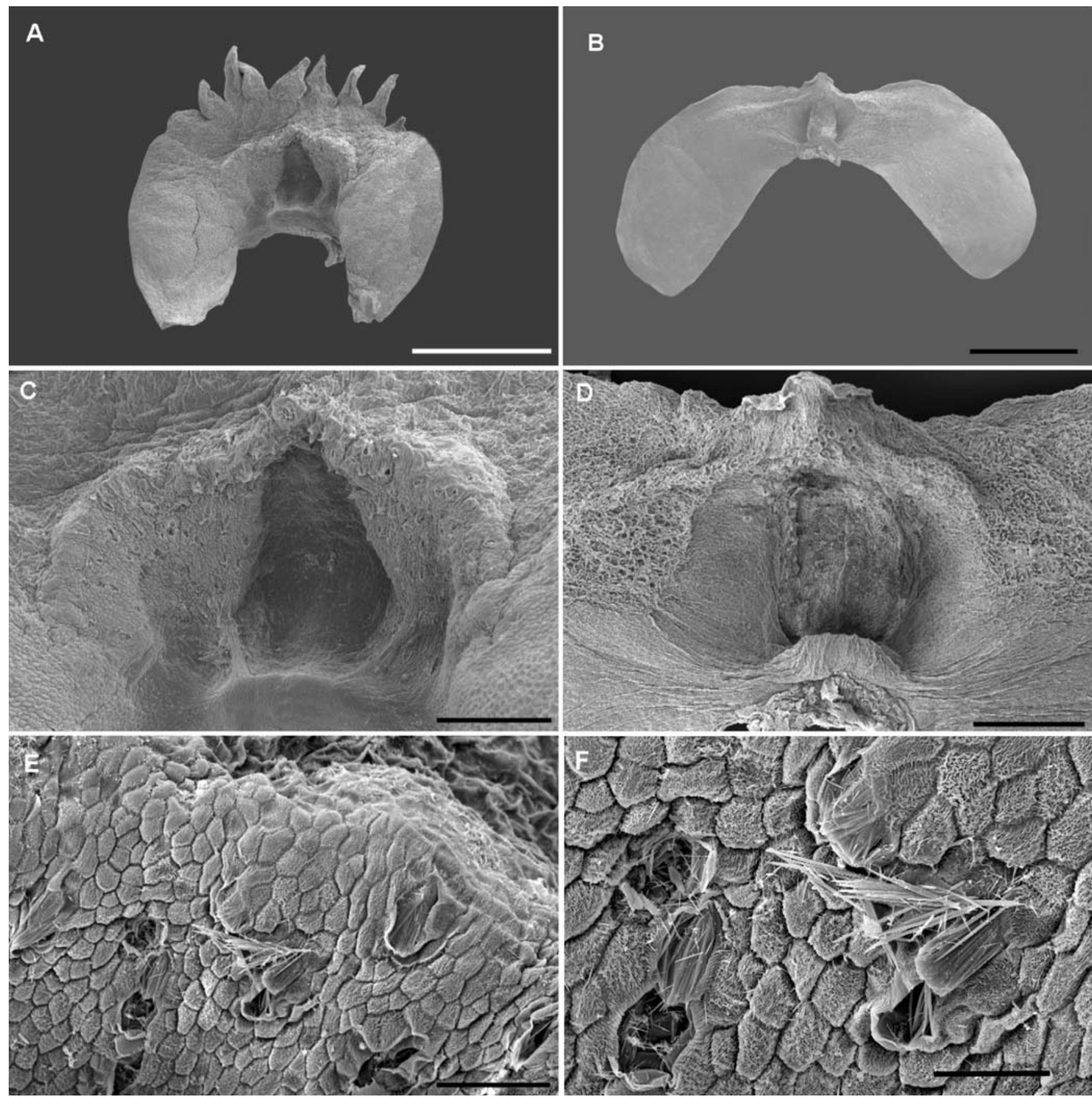

Fig. 10. Crepidium cf. rheedii: A - lip; C - cavity and lamina with OP structures; E, F - OP structures (see: the bulbous cell and raphides tipped from them); Crepidium dryadum: B - lip; D - cavity and roof with OP structures. Scale bars: A, B - 2 mm; C, D - $500 \mu \mathrm{m}$; E - $100 \mu \mathrm{m}$; F - 50 um (Kowalkowska).

DAVIES K.L., TURNER M.P., GREGG A. 2003. Ultrastructure of the labellar epidermis in selected Maxillaria species (Orchidaceae). Bot. J. Linn. Soc. 126: 349-361.

D'ARCY W.G., KEATING R.C., BUCHAMANN S.L. 1996. The calcium oxalate package or so-called resorption tissue in some angiosperm anthers. In: The anther. Form, function and phylogeny. W.G. D’Arcy, Keating R.C. (ed.). Cambridge University Press, Cambridge, UK. pp. 159-190.

DRESSLER R.L. 1993. Phylogeny and classification of the orchid family. Cambridge Massachusetts: Dioscorides Press.

FAHN A. 1979. Ultrastructure of nectaries in relation to nectar secretion. Am. J. Bot. 66: 977-985.

FAHN A. 1988a. Nectaries structure and nectar secretion. In: Nectary biology. Structure, function and utilization. B. Bahadur. Dattsons J.L. (ed.). Nehru Marg, Sadar, Nagpur, India.

FAHN A. 1988b. Secretory tissues in vascular plants. Nev. Phytol. 108: 229-257.
HASHIMOTO T. 1993. Novelties of the Genus Malaxis to Japan. Ann. Tsukuba Bot. Gard. 5(2): 1-8. 1993.

KURZWEIL H. 1987. Developmental studies in orchid flowers I: Epidendroid and vandoid species. Nordic J. Bot. 7: 427-42.

MARGOŃSKA H.B. 2002. Materials towards the revision of the genus Pseudoliparis Finet (Orchidaceae, Malaxidinae) - part 1. Ann. Bot. Fen. 40(1): 63-66.

MARGONSKA H.B. 2003. Materials towards the revision of the genus Pseudoliparis Finet (Orchidaceae, Malaxidinae) - part 2. section Oistochilus. Ann. Bot. Fen. 40(4): 357-372.

MARGOŃSKA H.B. 2005a. Contribution to the taxonomic revision of the genus Crepidium (Orchidaceae-Malaxidinae): the new subsection Maximowiczianae (section Hololobus) Edin. J. Bot. 62(3): 165-179.

MARGOŃSKA H.B. 2005b. A new combination and new subsection in Crepidium (Orchidaceae). Edin. J. Bot. 62(3): 193$-194$. 
MARGOŃSKA H.B. 2005c. Materials towards the revision of the genus Pseudoliparis Finet (Orchidaceae, Malaxidinae) - part 3. section Pseudoliparis. Ann. Bot. Fen. 42: 267-291.

MARGOŃSKA H.B. 2006a. Notes about genus Tamayorkis Szalch. with description of new species (Orchidales, Malaxidinea). Richardiana. 4(3): 123-129.

MARGOŃSKA H.B. 2006b. Seidenforchis - A new genus of subtribe Malaxidinae (Orchidaceae), from Thailand. Acta Soc. Bot. Pol. 75(4): 301-307.

MARGONSSKA H.B. 2007. Platystyliparis Marg. - A new genus of the subtribe Malaxidinae Richardiana 7(1): 33-41.

MARGOŃSKA H.B., KOWALKOWSKA A. 2008. Taxonomic revision of Asiatic genus Dienia Lindl. (Malaxidinae, Orchidaceae). Ann. Bot. Fen. 45: 97-104.

MARGOŃSKA H.B., SZLACHETKO D.L. 2001a. Saurolophorkis Marg. and Szlach., gen. nov. (Orchidaceae, Malaxidinae), a new orchid genus from New Guinea. Pol. Bot. J. 46 (1): 7-9.

MARGOŃSKA H.B., SZLACHETKO D.L. 2001b. Alatiliparis Marg. and Szlach., gen. nov. (Orchidaceae, Malaxidinae), a new orchid genus with two new species from Sumatra. Ann. Bot. Fen. 38: 77-81.

MARGOŃSKA H.B., SZLACHETKO D.L. 2001c. Materials to the revision of the genus Seidenfia Szlach. (Orchidaceae, Malaxidinae), with description of new species. Pol. Bot. J. 46 (1): 47-62.

MARGOŃSKA H.B., SZLACHETKO D.L. 2004. Disticholiparis Marg. and Szlach. - A new genus of subtribe Malaxidinae (Orchidales, Orchidaceae). Die Orchidee 55(2): 175-179.
MARGOŃSKA H.B., SZLACHETKO D.L. 2006. The taxonomic revision of the genus Orestias Ridl. (Orchidales, Malaxidinea) from Africa. Ann. Nat. Mus. Wien. ser. Bot. 107: 209-220.

PACINI E., NEPI M., VESPRINI J.L. 2004. Nectar biodiversity: a short review. Plant Syst. Evol. 238: 7-21.

PIJL van der L., DODSON C.H. 1969. Orchid flowers. Their pollination and evolution. Coral Gables. University of Miami Press, $214 \mathrm{pp}$.

PROCTOR M.C.F, YEO P., LARK A. 1996. The natural history of pollination. London. Harper Collins, $480 \mathrm{pp}$.

ROUBIK D.W. 2000. Deceptive orchids with Meliponini as pollinators. Plant Syst. Evol. 222: 271-279.

STPICZYŃSKA M., MATUSIEWICZ J. 2001. Anatomy and ultrastructure of the spur nectary of Gymnadenia conopsea $\mathrm{L}$. (Orchidaceae). Acta Soc. Bot. Pol. 70: 267-272.

STPICZYŃSKA M., DAVIES K.L., GREGG A. 2003. Nectary structure and nectar secretion in Maxillaria coccinea (Jacq.) L.O. Williams ex Hodge (Orchidaceae). Ann. Bot. 93: 87-95.

STPICZYŃSKA M., DAVIES K.L., GREGG A. 2005. Comparative account of nectary structure in Hexisea imbricata (Lindl.) Rchb.f. (Orchidaceae). Ann. Bot. 95: 749-756.

SZLACHETKO D.L., MARGOŃSKA H.B. 2006. Redefinition of the genera Malaxis Sol. ex Sw. Microstylis (Nutt.) Eaton (Orchidaceae, Malaxidinae). Acta Soc. Bot. Pol. 75(3): 229$-231$.

SZLACHETKO D.L., MARGOŃSKA H.B., KUŁAK M. 2008. Nomenclatoral changes in Liparis-complex (Malaxidinae, Epidendroideae). Acta Soc. Bot. Pol. 77(1): 35-40. 